\title{
MODERNISM, POSTMODERNISM,
}

AND THE SHORT STORY IN ENGLISH. POSTMODERN STUDIES

\section{Jorge Sacido, ed.}

Rodopi: Amsterdam, New York, 2012.

(by Isabel Mํa Andrés Cuevas. Universidad de Granada)

iandres@urg.es

The present volume is an inspiring collection of essays which succeeds in engaging the reader in a thought-provoking discussion on issues which are presently at the core of literary and artistic debates, such as the definition and delimitations of the short story, as well as the ideas and problematics of modernist and postmodernist creation.

Even though the attempt to reach a satisfactory definition of these concepts, and in particular of the extent to which different features and creative principles can be ascribed to each of these narrative modes seems far from being an easy task, the book represents a masterful compilation of studies which shed valuable light on these issues and provides the tools for a coherent analysis of the short story as influenced - in varying degrees - by the main tenets that constitute the bases of modernist and postmodernist writing.

Hence, the volume, which is part of the Postmodernist Studies collection, is articulated into four thematically and chronologically arranged parts, preceded by a seven-page introduction which ushers the reader into the various concerns that will be dealt with in the book, as well as an introduction and an opening chapter which serves as a fitting complement to the introduction. This chapter brilliantly points out the fundamental theoretical notions that are later developed throughout the subsequent chapters and the different analyses they propose on the basis of a sample of short narratives. In this initial essay, Sacido provides such an accomplished 


\section{Reviews}

overview of the different approaches to the notions of short story, as well as of the possible conceptualizations of modernism and postmodernism that his book becomes an essential source of reference for any scholar or common reader aiming to clarify questions such as the place of epistemology and ontology within the discourse on the modern and the postmodern, the rethinking of subjectivity from the late nineteenth century and over the subsequent decades, or the problem of representation according to modernist and postmodernist aesthetics, along with the confluence of this representational task with postcolonial debates and the necessity of providing an answer to otherness and marginalization.

A particular strength of this volume is the coherence it evinces from its very opening. Hence, the idea of the short story as a dialogue with the social and cultural circumstances surrounding it, namely the varying needs for creation and representation, the vicissitudes determining its production within the literary market, or its adaptability to multiple forms of expression becomes, throughout the different studies that constitute this volume, a unifying argument, as Chapter One clearly states. Nonetheless, this is never in conflict with the multiplicity of voices and points of view Sacido's volume offers, as will be discussed.

Hence, the essays collected in Part I, fittingly headed "Refocusing Modernism through the Short Story", deal with the problematics of the idea of modernism when applied to some of the shorter fiction of authors such as Djuna Barnes or Wyndham Lewis and encourage a reconsideration both of the origins of Modernist aesthetics and of the characteristics associated with it. Thus, in "The Short Story and the Difficulty of Modernism", Adrian Hunter remarks on the necessity for a reassessment of the germ of the modernist short story. For him, it is to be traced back to the achievements of certain fin-de-siècle authors, such as Arthur Morrison, Henry James, or Frederick Wedmore, and their concerns with aspects such as plotlessness, open endings, or the conception of the short story as a genre in which "writers give less and ask more [from readers]" (Pain 1916: 45-46). The imperative of re-conceptualizing the notion of modernism is also central to the analysis carried out by José María Díaz. In "Allegory and Fragmentation in Lewis's The Wild Body and Barnes's A Book", he pays attention to issues such as fragmentation, the lack of an epiphanic resolution, or the construction of characters - which become created, as Díaz explains, not by means of their psychological traits, but rather as allegorical embodiments of these very qualities -in order to highlight how this emphasis on the psychological becomes symptomatic of a new dimension of the modernist short story which diverges from hegemonic modernism. As Díaz points out, these texts by Barnes and Lewis essentially propose a rejection of unified meaning and a reflection, instead, of a chaotic reality. 


\section{Reviews}

After this reassessment of the roots and foundational principles of modernism, the book engages more explicitly in a discussion on the interaction between modernism and postmodernism and the different ways in which these converge with the short story. The essays collected in Part II of the book, "The Subject Vanishes: Modernist Contraction, Postmodernist Effacement and the Short Story Genre", provide a variety of approaches to the specific concern with the role of the subject in those narratives. This enables the reader to reach a multidimensional understanding of the position of the subject as relocated by the short story from modernism and beyond. The arrangement of the articles in this part matches the sense of unity and consistency that characterizes the totality of the volume. Accordingly, in "Man in a Sidecar: Madness, Totality and Narrative Drive in the Short Story", Tim Armstrong argues how aspects such as trauma and shock or the feeling of alienation that pervade the modern self find a means of representation in the modernist and postmodernist short story through self-encapsulated subjects that often become incapable of transcending their conditions of trauma, madness, or isolation. Fred Botting, in "Stories, Spectres, and Screens" explores the condition of the subject in modern society and, consequently, in the short stories within the parameters of modernism and postmodernism. Botting agrees with Armstrong on the emphasis placed in these narratives upon the fragmentation and insubstantiality of the subject, which is recurrently recreated, as Botting notes, in gothic fiction from the twentieth century. In these texts, the resort to phantasmagoreality and ghostscreens, along with the sense of uncanniness inherent to these presences evinces the hollow identity of the subject and the concern in these texts with presenting a discontinuous and utterly defamiliarized existence.

This revision of the repositioning of the subject in modernist and postmodernist short stories is skillfully complemented by Paul March-Russell's reflections on the progressive displacement of the individual as accomplished particularly in the science fiction stories by Ballard. In "The Writing Machine: J.G. Ballard in Modern and Postmodern Short Story Theory", March-Russell focuses on the mechanistic conception of the subject distilled by these stories as the point of departure for his theorization of the genre as an ever-evolving form of writing which escapes tight definitions of the modern or the postmodern.

The enthralling debate in which the reader is involved throughout the volume gains further complexity through the contrasting vision that the essays in Part III, "The Subject Reappears: Postcolonial Conflict and the Other's Stories", offer with respect to the analyses and conclusions in the previous section, Part II. These essays point towards a different approach regarding the subject in those cases in which notions of race, nation, or communal identity come to the fore. 


\section{Reviews}

Thus, in "Posmodernist Tales from the Couch", Esther Sánchez-Pardo focuses on the work of Delany and Crane to explore the way in which these authors exploit the elements of in-betweenness, flânerie or psychological insights in order to challenge preconceived ideas that perpetuate boundaries and fragmentation and to celebrate multiplicity, as associated with either sexuality, language, history, or identity. In “Mind the Gap: Modernism in Salman Rushdie's Postmodernist Short Stories”, J. Manuel Barbeito and María Lozano identify a type of modernist subjectivity in certain narratives by Rushdie traditionally classified as postmodernist. As they note, especially in the case of the stories collected in East, West - whose title strategically makes use of the comma as a means of representing division- Rushdie stresses the constitutive nature of the gap separating the colonies and the metropolis insofar as it becomes the locus from where subjectivity can be constructed on the basis of the very essence of its difference. This creation and reshaping from difference with respect to the normative is also the main focus of Manuela Palacios's study. In her essay, "One AnOther: Englishness in Contemporary Irish Fiction", she explores the encounter with the Other in a series of stories by Irish women in which it becomes evident that the gap between nations and identities remains unbridged. Nevertheless, as Palacios observes, it is precisely the non-compliance with normativity by the female protagonists of these texts and the construction of selfhood within the territory of that female Other that allows for the representation of a true identity.

A remarkable achievement of this volume is the up-to-date dialogue it establishes with present considerations and manifestations of the short story in English. Indeed, while discussions on modern and postmodern narrative tend to focus on a historical revision of a span of relatively recent literary production, Sacido's collection of essays concludes with a final chapter, "A Move against the Dinosaurs: The New Puritans and the Short Story", which examines the present state of the genre, as well as the latest tendencies in the writing of this fiction. In this essay, included in Part IV, "Short Notes from the Contemporary Underground", José Francisco Fernández assesses the work of a young generation of authors whose stories, published in anthologies such as All Hail the New Puritans, accurately contribute, according to Fernández, to determining the position of the short story nowadays, and at the same time to predicting to a certain extent the direction in which it seems to be moving. This final chapter provides an excellent closure to the book, inasmuch as it clearly puts forward one of the axial ideas around which the discussion in this multidimensional study spins: the open and fluid nature of the short story - a genre which eschews narrowness of definition and which transcends strictures of convention or delimitation within its own position at the margins. As Hunter notes: 


\section{Reviews}

The interrogative story's "unfinished" economy, its failure literally to express, to extend itself to definition, determination or disclosure, becomes, under the rubric of a theory of "minor" literature, a positive aversion to the entailment of "power and law" that defines the "major" literature (2007: 40).

Sacido's collection of essays becomes, therefore, a fundamental work of reference central to any discussion not only on literary theory and history, but also on the status of cultural forms of representation. Its engagement in the exploration of the tendencies and directions in the fiction of both canonical authors and writers from younger generations opens up some fascinating paths for the analysis and reconsideration of short fiction within the debated paradigms of Modernist and Postmodernist discourses.

\section{Works cited}

Hunter, Adrian. 2007. The Cambridge PAIN, Barry. 1916. The Short Story. London: Introduction to the Short Story in English. Secker.

Cambridge: Cambridge U.P. 